2014

\title{
Access to Justice and Corporate Accountability: A Legal Case Study of HudBay in Guatemala
}

Valerie Crystal

Shin Imai

Osgoode Hall Law School of York University, simai@osgoode.yorku.ca

Bernadette Maheandiran

Follow this and additional works at: http://digitalcommons.osgoode.yorku.ca/olsrps

\section{Recommended Citation}

Crystal, Valerie; Imai, Shin; and Maheandiran, Bernadette, "Access to Justice and Corporate Accountability: A Legal Case Study of HudBay in Guatemala" (2014). Osgoode Legal Studies Research Paper Series. 73.

http://digitalcommons.osgoode.yorku.ca/olsrps/73 


\title{
OSGOODE HALL LAW SCHOOL LEGAL STUDIES RESEARCH PAPER SERIES
}

Research Paper No. 43

Vol. 10/ Issue. 10/ (2014)

\section{Access to Justice and Corporate Accountability: A Legal Case Study of HudBay in Guatemala}

Crystal, V., Imai, S., \& Maheandiran, B. (2014). Access to justice and corporate accountability: A legal case study of hudbay in Guatemala. Canadian Journal of Development Studies, 35(2), 286-303.

Valerie Crystal

Shin Imai

Bernadette Maheandiran

\section{Editors:}

Editor-in-Chief: Carys J. Craig (Associate Dean of Research \& Institutional Relations and Associate Professor, Osgoode Hall Law School, York University, Toronto)

Production Editor: James Singh (Osgoode Hall Law School, York University, Toronto)

\author{
This paper can be downloaded free of charge from: \\ http://ssrn.com/abstract=2358981
}

Further Information and a collection of publications about Osgoode Hall Law School Legal Studies Research Paper Series can be found at:

http://papers.ssrn.com/sol3/JELJOUR_Results.cfm?form_name=journalbrowse\&journal_id=722488 
Osgoode Legal Studies Research Paper No. 43

Vol. 10/ Issue. 10/ (2014)

\title{
Access to Justice and Corporate Accountability: A Legal Case Study of HudBay in Guatemala
}

Crystal, V., Imai, S., \& Maheandiran, B. (2014). Access to justice and corporate accountability: A legal case study of hudbay in Guatemala. Canadian Journal of Development Studies, 35(2), 286-303.

Valerie Crystal

Shin Imai

Bernadette Maheandiran

\begin{abstract}
:
This case study looks at the avenues open for addressing serious allegations of murder, rape and assault brought by indigenous Guatemalans against a Canadian mining company. While first generation law and development reforms have facilitated foreign mining in Guatemala, "second generation" reforms have not yet provided a meaningful way of addressing conflicts arising from the development projects. The judicial mechanisms available in Guatemala are difficult to access and suffer from problems of corruption and intimidation. The corporate social responsibility mechanisms applicable to the mining company cannot provide enforceable orders. Canadian courts have been reluctant to permit law suits against Canadian parent companies. However, in Choc v. HudBay, an Ontario judge has allowed a case to proceed to a full trial on the merits of the case, providing an important, albeit limited, avenue for corporate accountability. Key words: mining, indigenous people, Guatemala, HudBay, corporate social responsibility, human rights, corporate accountability.
\end{abstract}

\section{Keywords:}

Mining, indigenous people, Guatemala, HudBay, corporate social responsibility, human rights, corporate accountability

\section{Author(s):}

Shin Imai

Associate Professor

Osgoode Hall Law School

York University, Toronto

E: simai@osgoode.yorku.ca

Bernadette Maheandiran

Swadron Associates

E: b.maheandiran@gmail.com
Valerie Crystal

Osgoode Hall Law School

York University, Toronto

E: ValerieCrystal@osgoode.yorku.ca 


\title{
Access to Justice and Corporate Accountability: A Legal Case Study of HudBay in Guatemala
}

By Shin Imai, Bernadette Maheandiran and Valerie Crystal*

\begin{abstract}
This case study looks at the avenues open for addressing serious allegations of murder, rape and assault brought by indigenous Guatemalans against a Canadian mining company. While first generation law and development reforms have facilitated foreign mining in Guatemala, "second generation" reforms have not yet provided a meaningful way of addressing conflicts arising from the development projects. The judicial mechanisms available in Guatemala are difficult to access and suffer from problems of corruption and intimidation. The corporate social responsibility mechanisms applicable to the mining company cannot provide enforceable orders. Canadian courts have been reluctant to permit law suits against Canadian parent companies. However, in Choc v. HudBay, an Ontario judge has allowed a case to proceed to a full trial on the merits of the case, providing an important, albeit limited, avenue for corporate accountability.

Key words: mining, indigenous people, Guatemala, HudBay, corporate social responsibility, human rights, corporate accountability
\end{abstract}

This is an Author's Original Manuscript of an article submitted for consideration in the Canadian Journal of Development Studies [copyright Taylor \& Francis] which is available online at http://www.tandfonline.com/.

\footnotetext{
${ }^{*}$ Shin Imai, Associate Professor, Osgoode Hall Law School of York University. Bernadette Maheandiran, Swadron Associates. Valerie Crystal, student at law, Osgoode Hall Law School. The authors would like to thank the following students for research assistance: Justin Dharamdial, Sarah Molyneaux, Sara Rohani and James Roundell. This article is an initiative of the Justice and Corporate Accountability Project at Osgoode Hall Law School.
} 


\section{Access to Justice and Corporate Accountability: A Legal Case Study of HudBay in Guatemala}

\section{INTRODUCTION}

In this paper, we will examine the history of one particularly troubled nickel mine in Guatemala, located near the town of El Estor in the region of Izabal. The mine was born into violence as Indigenous people living on the site were removed to make space for the mine and the town in the 1960s and 1970s. Numerous murders, assaults and other human rights violations have occurred as a result of the conflict between local Indigenous people who have lived in the area since the late nineteenth century and the successive Canadian corporate entities - INCO, Skye Resources, and HudBay Minerals, as well as their Guatemalan subsidiaries.

We will study the practical dimensions of this case in the context of "second generation" reforms in the law and development field that have introduced social and human rights issues as a component of the rule of law. While first generation reforms focused on judicial and institutional reforms to encourage an appropriate climate for commercial relations, second generation reforms introduced a number of voluntary, soft law mechanisms to address social, environmental and human rights aspects of development (Trubek 2006). However, they have been criticized for being more show than substance (Eslava 2008). Legal scholar Kerry Rittich suggests the need for specific case studies to determine how these social aspects are faring on the ground (Rittich 2006). We are not engaged in evaluating whether corporate social responsibility mechanisms or judicial reforms in Guatemala may have improved the conduct of individual corporations or judges, as the case may be. Rather, we are making a more specific point, that the current mechanisms do not provide meaningful access to justice for those who are most in need of the protection of the law.

Taking up Rittich's suggestion, we describe a dispute - centred around allegations of murder and rape - between Indigenous people in the El Estor region of Guatemala and Canadian mining company, Hudbay Minerals. We first look at the history and context underlying the dispute, including a decades-long struggle over land and resources. We believe that an understanding of the history of the conflict reveals the contextual factors driving the actions of 
specific individuals. We take the approach that second generation reforms must take into account history and context in a way that recognizes the interests and rights of Indigenous communities.

We then review three avenues for addressing that dispute: seeking resolution in the Guatemalan judicial system, relying on voluntary corporate social responsibility mechanisms and suing in Canada. We argue that both the Guatemalan courts and corporate social responsibility mechanisms present serious limitations with respect to resolving claims of human rights abuses by Canadian mining companies. We are concerned that while Canadian companies are permitted to profit from extractive activities in foreign jurisdictions, the Canadian court system has typically not stepped in to fill this gap with respect to the effects of those activities, finding either that the cases should be heard in foreign jurisdictions, or that Canadian mining companies do not owe a duty of care to people in foreign countries directly affected by Canadian mining.

A recent decision by the Ontario Superior Court of Justice may be an indication that Canadian courts are prepared to narrow this accountability gap. In this decision, the judge ruled that three law suits filed by Indigenous people of El Estor against HudBay may proceed to trial, as it is not "plain and obvious" that HudBay is not liable to the plaintiffs in negligence. Regardless of whether these plaintiffs succeed in proving their case, the openness of the Court to decide the issues on their merits provides an important precedent for those attempting to seek a remedy against a Canadian mining corporation for alleged wrongs committed abroad.

We wish to point out two limitations to our methodology. First, we are only studying the interests of the individuals who are plaintiffs in the law suit. While there are different views about mining and the events in the region within the Indigenous communities, we do not purport to generalize about interests in the Indigenous community as a whole. We feel that this is a valid approach, as we are studying the availability of legal remedies to complainants, not the dynamics of community relations. Second, we are limited by the evidence that we have available, from court documents, newspaper reports and our own personal knowledge of Guatemala. Consequently, while we present divergent versions of events, we do not attempt to draw conclusions about which version is correct, nor whether we have all the information. Rather, we show that there are serious issues raised that need to be resolved in a process that can make determinations of fact and, if appropriate, provide redress. 


\section{The ESTABLISHMENT OF INCO IN GUATEMALA ${ }^{1}$}

The Canadian mining company $\mathrm{INCO}^{2}$ first became involved in the Izabal region of Guatemala in 1960, through Exmibal, a subsidiary established with the U.S.-based Hanna Mining Company (McFarlane 1989). The history of INCO in Guatemala shows that Canadian mining interests were promoted by the Canadian government, and yet the Canadian government did not take initiative to address corporate accountability for the violence associated with the Canadian mining operations.

INCO planned to build an open-pit nickel mine near the town of El Estor, located north of Lake Izabal in the department of Izabal in eastern Guatemala. However, there were two immediate obstacles to the realization of INCO's objective. First, open-pit mining was prohibited under Guatemalan law. Second, in 1960, civil war began in Guatemala and the area around El Estor became the base of operations for guerrilla rebels (McFarlane 1989).

INCO was able to surmount these difficulties through negotiations with Guatemala's military government. INCO hired an engineer to re-write the mining code, and this revised version was accepted by the Guatemalan Congress (McFarlane 1989). The resulting mining code of April 1965 specifically allowed for "open sky mining" (Driever 1985, 34). The company also received a 40-year lease to mine an area $385 \mathrm{~km}^{2}$ in size near El Estor as well as "generous tax concessions". Finally, the military government provided INCO with the understanding that it would guarantee "stability" in the region (McFarlane 1989, 127).

Colonel Carlos Arana Osorio ${ }^{3}$ was responsible for clearing the Indigenous people out of the INCO region in Zacapa-Lake Izabal in the late 1960s and 1970s (McFarlane 1989, Bradbury 1985). The Indigenous people of Izabal were largely Mayan Q'eqchi', who had migrated to the area from the highlands of Verapaz in the late nineteenth century (Grandia 2006). During this "reign of terror", the number of people killed is estimated to be between three and six thousand (McFarlane 1989, 127). At the same time, Canada showed ongoing support for the El Estor project, as the Canadian ambassador to Guatemala, S.F. Rae, went on a well-publicized tour of the mine site in 1968 (McFarlane 1989).

There was strong opposition to the Exmibal project from Indigenous people and other concerned Guatemalans. A group of professors from the School of Economic Sciences at the University of San Carlos, Guatemala City, took up the cause and established a commission in 
1969 (McFarlane 1989). The commission concluded that the Guatemalan government had not negotiated sufficient benefit from the project and that Exmibal would simply strip Guatemala of its riches (Driever 1985, 36). Public protests against the mine followed. Carlos Arana, now President of Guatemala, responded by suspending the constitutional right to assembly and arresting large numbers of people. The army occupied the university in its attempt to silence the opposition from the nation's intellectual community. State death squads assassinated two law professors and members of the commission, Julio Camey Herrera and Adolfo Mijangos López. One other member of the commission was wounded in an assassination attempt and another was forced to flee the country due to death threats (Ball, Kobrak, and Spirer 1999; Bradbury 1985). The UN Commission on Historical Clarification later found that these crimes were committed because of opposition to the government's policies (Guatemalan Commission for Historical Clarification 1999).

In February 1971, an exploitation agreement was signed between INCO and the Guatemalan government. Major construction began on the El Estor mine in 1974 (Driever 1985) aided by a \$20 million loan from the Canadian Export Development Corporation (Lewis 1979). The UN Commission documented violence associated with the mine during this period. In 1978, two people in El Estor were shot and wounded by men riding in an Exmibal truck (Guatemalan Commission for Historical Clarification 1999, 679). The next month, employees of Exmibal were involved in the execution of four people in the municipality of Panzós, near El Estor (Guatemalan Commission for Historical Clarification 1999, 105). In 1981, police officers riding in an Exmibal truck killed community leader Pablo Bac Caal (Guatemalan Commission for Historical Clarification 1999, 674).

In 1982, the market value of nickel was declining while the cost of oil was rising. As a result, INCO shut down the El Estor mine. While the mine lay dormant, violence in Guatemala continued. The most serious human rights violations were perpetrated under the dictator Rios Montt. There were 192 massacres in 1982 alone. ${ }^{4}$ Despite condemning these human rights violations in Guatemala in 1983, the Canadian government participated in negotiations to sell military planes to the Guatemalan air force. The Guatemalan military had been known to use their planes to shoot at Indigenous villages (Lemco 1986).

In 1996, the Guatemalan government signed a Peace Accord with the guerrillas, ending the 36-year civil war. According to a 1998 report by Monsignor Juan Gerardi which evaluated 
evidence and testimony of 600 people collected from across Guatemala over three years, 150,000 people were murdered, 50,000 disappeared and one million were displaced during the civil war (Gerardi 1998). In a 1999 report, Guatemala: Memories of Silence, the UN Commission found that the state, in some capacity, was responsible for 93 per cent of the human rights violations that occurred during the war and that the state had "committed acts of genocide against groups of the Maya people" (United Nations 2002, 2).

\section{The FenIX ProjeCt}

In 2004, a Canadian company called Skye Resources purchased the mine at El Estor. At that time, the mine came to be known as "Fenix" and was to be operated by Skye's Guatemalan subsidiary Compañia Guatemalteca de Níquel (“CGN”). As INCO’s original mining concession from the 1960s was set to expire, the Guatemalan government granted a licence for mining exploration at El Estor on December 13, 2004 (International Labour Organization 2007, 40). According to a committee of the International Labour Organization ("ILO"), despite the fact that Indigenous people had not yet formalized their rights of ownership and possession with respect to the land in question, the Guatemalan government had an obligation under ILO Convention No. 169 to consult with the affected Indigenous people prior to granting the licence, which it had failed to do (International Labour Organization 2007, paras 48-51).

The Mayan Q'eqchi' farmers in the Izabal region gradually began to occupy or reoccupy lands in El Estor that had been cleared of Indigenous people for the mine in the 1960s and 1970s. New settlements were formed on these lands, including the community of Barrio Revolución, and other communities, such as La Unión, were reoccupied (Paley 2007).

Skye Resources referred to the reoccupation of the El Estor region as "land invasions" (Skye Resources 2007). Because of Skye Resources' belief that it had the exclusive right to occupy the area, court orders were obtained in order to remove the "squatters". 5 On January 8 and 9, 2007, hundreds of armed police officers and members of the military conducted forced evictions of five communities in the El Estor region, including Barrio Unión, La Pista, Barrio Revolución, Barrio La Paz, and Lote Ocho (Paley 2007, Caal v. Hudbay 2011). During the evictions, people's homes were destroyed and some were burned (Paley 2007).

According to Skye Resources, "a peaceful atmosphere" was maintained during the evictions (Skye Resources 2007). President and CEO Ian Austin admitted that homes were 
burned, but claimed that the burning of homes was not caused by company people (Canadian Broadcasting Corporation 2011). He stated that the company remains committed to "continue [its] discussions on matters of concern with the local communities in the El Estor region" (Skye Resources 2007).

According to allegations in court documents, another set of evictions occurred on January 17, 2007. During these evictions, eleven Mayan women of Lote Ocho were allegedly gang-raped by police, military, and Fenix security personnel. The women say that they were trapped by security personnel as they were attempting to leave their homes, and then raped by groups of men, including members of the Fenix security team who were wearing uniforms bearing the initials "CGN". Two of the women were pregnant at the time of the alleged rapes, and subsequently miscarried their unborn children (Caal v. HudBay, 2011). CGN denies that these rapes occurred. According to the company, police reports show that no "illegal occupiers" were even present at the evictions on the date of the alleged rapes (HudBay Minerals n.d.).

The Fenix mine changed ownership again in 2008, when HudBay Minerals purchased Skye Resources, changing the name of Skye Resources to HMI Nickel (HudBay Minerals 2008a, HudBay Minerals 2008b). HudBay announced that it did not plan to begin construction at the Fenix site until market conditions became more favourable (HudBay Minerals 2008b). During this time, some of the Mayan Q'eqchi' people returned once again to the disputed land.

In 2009, nickel was rising in price, and the company began considering spending the $\$ 1$ billion necessary to open the mine (Grainger 2009). On September 27, 2009, there were protests against mining activities in several communities located near the Fenix mine, including in the communities of La Unión and Las Nubes. Violence erupted that day resulting in seven people being shot, the death of community leader and school teacher, Adolfo Ich Chamón, and serious injury to another community member, German Chub Choc. Five security guards were also injured.

The series of events that led up to the violence are in dispute. According to one version of events, the governor of Izabal along with fifty CGN security guards entered the community of Las Nubes in order to discuss resettlement of the community (Behrens 2009). These discussions lasted for a few hours, but did not lead to an agreement. In response to CGN's presence, community members organized protests in order to assert their right to remain on the land. Adolfo Ich's family claims that protests were sparked by the "intrusion of Fenix security 
personnel into Mayan Q'eqchi' communities" and "fears of renewed forced and violent evictions" (Choc v. HudBay 2010, para. 51). Residents of La Unión joined those of Las Nubes in a march toward the town of El Estor to denounce "illegal evictions" and to gather support for their cause (Rodriguez 2009). At around three in the afternoon, security guards reportedly opened fire on community members, wounding eight people (Behrens 2009). According to the Ich family's statement of claim, Adolfo Ich was in his home in La Unión when he heard gunshots being fired. He left his home in order to see what was going on and to see if he could help restore the calm (Choc v. HudBay 2010). As he was a respected community leader, he was apparently recognized by security personnel. The claim states that he was unarmed when he was surrounded by a dozen armed CGN security guards who beat him, dragged him away, and severed his arm with a machete. The head of CGN security, Mynor Padilla, is alleged to have shot him in the head. Padilla is a former high-ranking officer in the Guatemalan military.

An alternative version of events is provided by HudBay. According to the company, authorities were attempting to "peacefully resolv[e] illegal occupations through dialogue" when “organized protestors" attacked departing government vehicles (HudBay Minerals 2009). HudBay claims that the protestors stole automatic firearms and other weapons from the police station and attacked a community hospital, which had been sponsored by CGN. HudBay acknowledged that a protestor died that day; however, it claims that "CGN personnel were not involved with his death" (HudBay Minerals n.d.). HudBay suggested that Ich died as a result of a "confrontation among the protestors" (HudBay Minerals 2009). The company expressed its commitment to working with residents to arrive at a "fair and equitable solution to the land claims and resettlement". Regardless of which version of events is believed, the incident highlights the ongoing tensions occurring in the area as a result of unsettled land claims.

\section{The Three CASES From El ESTOR}

Members of the Mayan Q'eqchi' communities around the Fenix mine are bringing three related lawsuits in the Ontario Superior Court of Justice against the Canadian mining company HudBay Minerals. The first lawsuit was commenced on September 24, 2010 by the widow of Adolfo Ich Chamán who was killed during the time of the protests around El Estor in September 2009. As discussed above, the claim alleges that Adolfo Ich was "hacked and shot to death by private 
security forces employed by [CGN] near his home in El Estor, Guatemala" (Choc v. HudBay 2010, para. 1).

The claim made by Adolfo Ich's widow is that HudBay, both in Canada and Guatemala, was negligent in deploying security forces into the community of La Unión and in authorizing the use of excessive force in response to the peaceful opposition, despite the corporation being aware that the security personnel were unlicensed, using illegal weapons and had in the past used unreasonable violence against local Mayan populations. Further, the allegation is that HudBay continued to employ under-trained and inadequately supervised security personnel, and, regardless of public commitments to the contrary, failed to implement or enforce adequate standards of conduct and oversight which would have prevented the murder of Adolfo Ich.

On the same day that Adolfo Ich was shot, German Chub was allegedly shot by the same mine company security personnel (Chub v. HudBay 2011). The then 21-year-old, single father has been left a paraplegic by the shooting and has lost the use of his right lung. He had not been involved in any protests on that day but was watching a football game at a community football field and was shot without provocation. On October 26, 2011, Chub commenced a lawsuit against HudBay Minerals and CGN, similarly alleging that the violence against him was caused by negligent authorization of the deployment of heavily armed security personnel into Mayan Q'eqchi' communities on September 27, 2009.

The final lawsuit against the corporation relates to the forcible evictions of the community of Lote Ocho that took place in January 2007 as discussed above. Eleven women, Margarita Caal Caar, Rosa Elbira Coc Ich, Olivia Asig Xol, Amalia Cac Tiul, Lucia Caal Chun, Carmelina Caal Ical, Irma Yolanda Choc Cac, Elvira Choc Chub, Elena Choc Quib and Irma Yolanda Choc Quib, have commenced an action against HudBay Minerals and HMI Nickel for the alleged gang rapes by uniformed mining company security personnel, police and military during the forceful expulsion of Mayan Q'eqchi’ families (Caal 2011 v. HudBay).

The claim alleges that the security forces that committed the rapes were under the control and direction of Canadian mining company Skye Resources which sought the forced eviction in order to clear the land of the Indigenous communities for its Fenix Mining Project. In 2008, HudBay Minerals bought and merged with Skye Resources (renamed HMI Nickel), which the claim asserts makes HudBay responsible for the past legal wrongs and liabilities of Skye Resources. The lawsuit alleges that the harm suffered by the plaintiffs was caused by the 
negligence of Skye Resources in failing to direct and supervise its security personnel, knowing that they lacked the licence required under Guatemalan law, and in authorizing the forced evictions without taking reasonable steps to control violence against the community, although it made public representations to the contrary.

In September 2011, HudBay sold the Fenix mine and all of its Guatemalan assets to Solway Investment Group, a private company with a head office in Cyprus (HudBay Minerals 2011). While HudBay had purchased the mine for $\$ 446$ million, it was sold for only $\$ 176$ million (Canadian Broadcasting Corporation 2011). The lawsuits against HudBay are proceeding despite the sale (Klippensteins n.d.).

On July 22, 2013, Justice Carole J. Brown of the Ontario Superior Court of Justice rejected three preliminary motions filed by HudBay and allowed the three cases to proceed to trial.

\section{The Context for JUdicial Decision-Making in GuATEMAla}

The plaintiffs in the three El Estor cases have decided to pursue their claims against HudBay in Canadian courts, rather than in Guatemala. There is good reason for Canadian courts to hear cases like these on their merits, given the context for judicial decision-making in Guatemala. This section will outline the state of impunity in Guatemala as expressed by international bodies and will then provide an example of a case which made its way through the Guatemalan courts in order to illustrate the difficulties faced by plaintiffs who wish to receive a fair trial in a claim against the interest of foreign mining companies.

According to a 2009 report of the UN Special Rapporteur on the independence of judges and lawyers, Leandro Despouy, the Guatemalan justice system is afflicted by a general climate of impunity for violent crimes and human rights abuses:

... the prevalence of impunity in Guatemala has a number of causes, the main ones being a variety of structural factors and the violence to which justice professionals are subjected.... The existing system is open to external interference and is highly politicized, and this has a negative impact on the independence of the judiciary (United Nations 2009a). 
Similarly, the 2012 Human Rights Report on Guatemala prepared by the U.S. Department of State asserts that the Guatemalan judicial system has failed "to ensure full and timely investigations and fair trials" and to "protect judicial sector officials, witnesses, and civil society representatives from intimidation" (US Department of State 2012, 1). It notes that "[j]udges, prosecutors, plaintiffs, and witnesses continued to report threats, intimidation, and surveillance" (US Department of State 2012, 7).

This situation has improved to some degree since the establishment of the UN-backed International Commission Against Impunity in Guatemala ("CICIG"); however, the UN Special Rapporteur on extrajudicial, summary or arbitrary executions cautions that "neither Guatemala nor the international community should fall into the trap of seeing CICIG as 'the' solution to Guatemala's failing criminal justice system" (United Nations 2009b), and the U.S. Department of State report observes that "impunity continued to be widespread" despite the efforts of the CICIG (US Department of State 2012,1). ${ }^{6}$

As an illustration, we describe a case from Guatemala's Constitutional Court in which the claimants were required to pursue an excessive number of judicial proceedings in order to obtain a remedy for a relatively simple problem involving formal title to communal property. The community of Agua Caliente Lote Nueve located near the Fenix project in El Estor complained that CGN was illegally exploring on its land and said that mining personnel moved boundary stones and made exploration holes, which affected the community's water (Constitutional Court 2011). ${ }^{7}$ The community asked Fontierras ${ }^{8}$ to confirm that the community of Lote Nueve had title to its land. There was a problem with this request, and the resolution to this problem reveals much about the judicial system and its potential influences.

Under a land reform statute, communities were able to purchase land to hold under communal title. The community in this case began paying for the land in 1985 and was awarded provisional title, conditional on completing the scheduled payments. They made the final payment on July 18, 2002. In 2004 the mine was being transferred from INCO to Skye Resources. On July 2, 2004, Fontierras informed the community that the Registry book had been damaged in 1998 and that the pages of the Registry that contained their title were missing. Fontierras told the community that they would have to go to court to obtain an order to replace the pages. 
The same year, the community went to the Ninth Judge of the Civil Trial Court. Their case was rejected because the judge held that the community had begun the wrong process for the remedy that they were seeking. The community then went to the Tenth Judge of the Civil Trial Court, but were rejected because the document certifying the legal status of the representative was illegible. The community returned to the Tenth Judge, who then found that there was no certification that the land claimed was the land that was referred to in the missing pages. In 2007, the community again appealed to Fontierras for assistance. They were rebuffed a second time, and told that they needed to obtain a judicial order. When the community returned to court, this time the Sixth Judge of the Civil Trial Court, their case was dismissed because the community had failed to provide proof that the missing pages referred to the land that they were claiming. The community returned to Fontierras to ask them to replace the pages, and they were told a third time that a court order was necessary. Finally, the community began a constitutional proceeding, arguing that their constitutional rights had been violated because of the refusal of Fontierras to confirm their title.

The first level of hearing on a constitutional application went to the Court of Appeals on February 15, 2010. This was a year after HudBay had been considering reactivating the mine and had been trying remove Indigenous occupants from lands needed for the mine. The judge found that the community already had title confirmed on February 17, 2004 and that Fontierras had replaced the missing pages, pursuant to an order from the Fifth Judge of the Civil Trial Court on December 20, 2004. Consequently, there was no basis for the proceeding. The judge ordered costs against the community and fined the lawyer 1,000 quetzales (approximately \$130) for bringing the proceeding. The judge of the Court of Appeals ignored the history of the community being shunted back and forth between the courts and Fontierras, because he based his decision on the documents from another community, Agua Caliente Sexan Lote Once.

The community of Lote Nueve appealed this decision, and was able to present its case to the Constitutional Court in 2010. Lawyers for Fontierras and lawyers for CGN intervened to ask the Constitutional Court to uphold a decision that was clearly based on mistaken documents. Fortunately for the community, the Court found in their favour, and confirmed that the Court of Appeals had relied on mistaken documents. The Constitutional Court reviewed documents that confirmed that the provisional title had been awarded in 1985 and documents that confirmed that the final payment had been made. The judges came to the conclusion that the only step 
remaining was the administrative act of confirming title. The Court then ordered that the missing pages be replaced, confirming community title to the land.

It was unnecessary for land title to be thrown into limbo for seven years when the evidence that fulfilled the conditions for title was readily available. It is interesting that the missing pages were noticed at around the same time as exploration was taking place on their land, and as the mine was being sold by INCO to Skye Resources. Without more facts, we do not know whether CGN had a more active role in the circumstances surrounding Lote Nueve's title, but we do know that HudBay had an interest in the outcome of the hearing at the Constitutional Court, as lawyers for CGN intervened and argued that the community of Lote Nueve should not have their title confirmed. As of May 2013, two years after the Constitutional Court decision, the missing pages in the registry have not been corrected.

We do not argue that it is impossible to obtain a fair trial for a claim against the interests of a mining company within the Guatemalan justice system. Nevertheless, the barriers faced by plaintiffs who wish to sue mining companies in Guatemala are significant, and they are compounded by the difficulty in retaining a lawyer for cases such as these. The Lote Nueve case, for example, was supported by Leo Crippa, a lawyer for the Washington-based Indian Law Resource Centre.

A further problem exists with respect to the availability of remedies. A decision of a court in Guatemala against CGN alone will not reach the conduct of executives in Canada, or the assets of the Canadian parent. Even if a Guatemala court were to make an order against the parent company, HudBay Minerals, enforcement would have to be transferred to a court in Canada, where further litigation could take place challenging the original decision in Guatemala. This will further lengthen an already arduous process and render it prohibitively expensive.

\section{CORPORATE SOCIAL RESPONSIBILITY}

If claimants such as those from El Estor are unable to obtain a fair trial in the Guatemalan courts, it may be suggested that corporate social responsibility ("CSR") mechanisms adopted by mining companies may provide appropriate redress. We argue in this section that the voluntary nature of CSR and the lack of enforcement mechanisms make it an inadequate forum for resolving cases in which there are allegations of serious human rights abuses and significant factual discrepancies between the positions of the claimants and those of the company. 
In recent years, there has been an increasing interest in, and adoption of, corporate social responsibility polices by the mining industry (Dashwood 2012; Sagebien and Lindsay 2011). The establishment of the United Nations "Guiding Principles on Business and Human Rights" framework ("Ruggie Principles") provided further impetus to developing standards of behaviour that address a company's impact on the environment and local communities (United Nations 2011).

HudBay heavily promotes its commitment to CSR. Its website shows that HudBay has internal policies on human rights, the environment and business ethics. It has also adopted a number of external instruments including the Voluntary Principles on Security and Human Rights (Voluntary Principles on Security and Human Rights n.d.), the Global Reporting Initiative (Global Reporting Initiative n.d.) and the "Toward Sustainable Mining" framework of the Mining Association of Canada (Mining Association of Canada 2011). Each year, it publishes an attractive fifty page "Corporate Social Responsibility Report", setting out its accomplishments (HudBay Minerals 2012).

We do not propose to describe and analyze each of these CSR policies, nor do we wish to suggest that HudBay is being disingenuous in adopting these standards. Rather, we wish to show that the policies will not serve as an adequate mechanism for addressing the issues raised by the Guatemalan plaintiffs.

The 2012 Corporate Social Responsibility report lists four "avenues available to people who wish to register concern about HudBay's activities" (HudBay Minerals 2012, 13). The first two avenues provide phone numbers and a website to the Board or a Committee of the Board to register a concern. In the case of the Guatemalan plaintiffs, this avenue would not have been fruitful for serious criminal charges, as HudBay released a press release saying that its own investigations had shown that "a protestor died" but that company personnel were not involved; and that rapes did not take place (HudBay Minerals n.d.). Hudbay maintains this position despite the arrest of Mynor Padilla in 2012 for the murder of Adolfo Ich Chamán (Prensa Libre 2012). Given that HudBay had already publicly declared its own finding of fact, the plaintiffs would not expect to have a fair hearing from HudBay.

The third avenue of redress suggested by HudBay is the federal government's Corporate Social Responsibility Counsellor. In 2009, the federal government released a policy called "Building the Canadian Advantage: A CSR Strategy for the International Extractive Sector", 
which established the Office of the Extractive Sector Corporate Social Responsibility Counsellor. The CSR Counsellor does not have any significant powers. She can only act when there has been a complaint; a process can be instituted only with the agreement of the corporation; it cannot offer determinations as to whether harm has occurred; it cannot investigate the complaints; and it cannot issue binding recommendations on the corporations (Department of Foreign Affairs n.d.). The limitations of the process are clearly illustrated in a complaint about labour practices that was lodged against a Canadian mining company, Excellon Resources Inc., in Mexico. The CSR Counsellor found that the Mexican workers were "eager to engage in a good faith dialogue", but Excellon unilaterally withdrew from the process after six months. This brought the process to an abrupt end (CSR Counsellor 2011). For the Guatemalan plaintiffs, the most that the CSR Counsellor could do would be to convene a meeting. Even if HudBay agreed to participate, she would not be able to investigate what happened, nor assign a penalty if there was wrongdoing.

The final mechanism suggested by HudBay is the National Contact Point of the Organization for Economic Development and Co-operation (OECD). The OECD has developed "Guidelines for Multinational Enterprises" which state that corporations should "respect the internationally recognised human rights of those affected by their activities" (OECD 2011, 19). In order to implement the Guidelines, the OECD Council created a system of National Contact Points (NCP) in 2000 who are typically government officials in each of the member states. The role of the NCP is to facilitate inquiries and discussions between corporations and affected communities on all matters covered by the Guidelines. The NCP has some capacity to investigate complaints directly by seeking information from parties to the dispute and can attempt to mediate between the parties in order to come to a resolution. Neither the resolution nor the statement is binding on the corporation and is not enforceable by state governments. The NCP does have fact-finding powers but these are not commonly used. The NCP does not have the power to award compensation. If there is no resolution, the NCP can review the evidence, consult experts, make a determination and issue a statement on the case (OECD 2011).

None of these mechanisms suggested by HudBay can provide an effective method for investigating whether the allegations are true, for ascertaining responsibility, nor for awarding penalties or redress. For this reason, we turn in the next section to the Canadian courts as the 
remaining potential avenue to fairly resolve the dispute between the plaintiffs from El Estor and HudBay.

\section{The Courts IN CANAdA}

Having a case decided in a Canadian court has the advantage of producing an enforceable decision. A judgement against the parent company, HudBay, could result in payments to the plaintiffs and could shed light on the conduct of the executives.

Judges in Canada have had several occasions to address concerns with the activities of mining companies with operations abroad. They have articulated three principles that create barriers to bringing a case in Canada - lack of jurisdiction, forum non conveniens and lack of duty of care. ${ }^{9}$

We will discuss each of these principles in the context of a case against a transnational mining company and then explain how these principles play out in the law suits from El Estor.

\section{(i) Jurisdiction}

On November 8, 2010, the Canadian Association Against Impunity brought a class action against Anvil Mining Ltd. in Quebec for the corporation's actions relating to a massacre in the DRC (Mining Watch 2010). Anvil Mining was headquartered in Perth, Australia but opened a small office in Montreal in 2005. Its primary activity was the exploration of a mine located 55 kilometres from Kilwa in the DRC (Association Canadienne Contre L'impunité (ACCI) c Anvil Mining Ltd. 2011).

On October 13, 2004, a small group of approximately ten armed individuals from neighboring Zambia claiming to act on behalf of the Revolutionary Movement for the Liberation of Katanga, entered Kilwa. The Government of the DRC ordered army officers to remove the men and to regain control of Kilwa. A UN Mission in the DRC subsequently documented the army's human rights violations against the people of Kilwa perpetrated during the counterattack (Mission in the Democratic Republic of Congo 2005). According to the Mission report, 73 civilians were killed and a large percentage of the population had been displaced, fleeing the counterattack. Twenty-eight people were reported to have been summarily executed based on suspicions that they supported the insurgents. 
The Mission report stated that Anvil provided support to the military during the events by using its planes to transport troops to Kilwa, and by providing trucks, drivers, fuel, and food rations to the army. It also stated that the managing director of Anvil Mining admitted in an interview with an Australian television station that the corporation provided logistics to the army. The Quebec Court of Appeal dismissed the action on the basis that the Court had no jurisdiction. It found that at the time of the massacre, there was no activity or office in Quebec, and that, in any event, the dispute was not substantially connected to Anvil's work in Quebec. The Court did not apply the forum of necessity exception, which permits the Court to assume jurisdiction where there is a sufficient connection to the forum and proceedings could not possibly or reasonably be instituted outside Quebec (Civil Code of Québec, art. 3136). The Court found that the claim against Anvil could be heard in Australia, the corporate headquarters, and that victims could bring their case before the courts in the DRC, despite the unsuccessful attempts made to try the cases in those jurisdictions before.

Anvil's overall revenue for the DRC rose from \$29 million in 2004 to almost \$69 million in 2005 (Anvil 2005).

While the issue of jurisdiction may be a significant obstacle to foreign plaintiffs wishing to bring claims against Canadian mining companies, this was not contested by HudBay.

\section{(ii) Forum Non Conveniens}

As noted above, even where a court accepts jurisdiction, the defendant company can assert that there is a more appropriate forum where the claim can be heard. In 1998, a class action was brought in Quebec against Canadian mining corporation Cambior Inc. by a group of 23,000 victims represented by a public interest group, Recherches Internationales Québec. The claim alleged that a failed tailings dam leaked 2.3 billion litres of liquid containing cyanide and heavy metals into the Esequibo River in Guyana on August 19, 1995. Justice Maughan who was hearing the case described the leak as one of the worst environmental disasters in gold mining history (Recherches Internationales Québec v. Cambior Inc 1998).

The action was dismissed without being heard on the merits. The Quebec Superior Court ruled that it had jurisdiction but applied the legal doctrine of forum non conveniens codified in the Quebec Civil Code. The Court based its decision on the fact that Guyana was the location of the spill, the location of many of the witnesses and victims, the location where the damage was 
suffered and that Guyanese law would apply to the incident. Further, the Court noted that its decision not to hear the case did not deny the victims justice, since "Guyana's judicial system would provide the victims with a fair and impartial hearing", rejecting the claim that "the administration of justice is in such a state of disarray that it would constitute an injustice to the victims to have their case litigated in Guyana" (Recherches Internationales Québec v. Cambior Inc. 1998, para. 12). The victims did pursue their claim in the Guyana courts, but due to failure to file an affidavit, the action was struck by the High Court of the Supreme Court of Judicature of Guyana in 2006 and the plaintiffs were ordered to pay the company's legal costs (CNN Money 2006). Cambior continued to operate profitably until 2005 when the mine was exhausted (Guyana Office for Investment n.d.).

HudBay initially argued that the case should be heard in Guatemala, but abruptly dropped this ground of objection shortly before a hearing on the matter (Klippensteins n.d.).

\section{(iii) Duty of Care}

A component of establishing that a mining company is responsible for human rights abuses is the existence of a legal obligation to take reasonable care in the conduct of mining operations that could foreseeably harm the interests of the claimants. In Canada and in many other common law jurisdictions, duty of care is established when the court determines that (1) the harm suffered is "reasonably foreseeable" as a result of the defendant's conduct; and (2) there is a relationship of "proximity" between the defendant and the claimant, such that the defendant should be required to contemplate the claimant's legitimate interests when acting (Donoghue v. Stevenson 1932).

In the context of transnational corporations, there are several obstacles to finding such a relationship. Owing to legal requirements of the country where the mining is taking place or in order to avoid financial liability, a subsidiary of the parent corporation is often incorporated in the country of operations to conduct the extraction or production of the mineral resource. The subsidiary is in charge of day-to-day operations on the ground, which often include hiring and training employees, conducting exploration, and maintaining the mine. Where third parties, such as private security companies hired by subsidiary corporations, commit violence, it may be difficult to impute their wrongdoing to the parent corporation. The difficulty in establishing duty of care was evidenced by the suit commenced in 2008 against two of the directors of Copper 
Mesa, a Canadian mining company in Ecuador, as well as the Toronto Stock Exchange (TSX). The claimants, Ecuadorian campesinos from areas adjacent to Junin, where Copper Mesa attempted to carry out exploration activities, opposed the proposed mine (Klippensteins 2009, para. 13-15). Prior to Copper Mesa being listed on the Toronto Stock Exchange (TSX), the mayor of the county informed the TSX of the opposition to the mine in the community and the likelihood of violence.

On December 2, 2006, a large group of armed members of security forces confronted members of the Junin community and sprayed pepper spray directly into the eyes of one of the claimants. The security forces then shot into the crowd injuring another of the claimants. A representative of the community met with the defendant directors on April 27, 2007 to advise them of the confrontation and risk of violence. However, the violence continued. One of the plaintiffs was alleged to have received death threats in June 2007 and one month later was allegedly attacked by a mob led by affiliates of the corporation, who assaulted him with sticks and rocks before the police intervened (Klippensteins 2009). ${ }^{10}$

The Ontario Court of Appeal found insufficient evidence to hold the directors personally liable, upholding the determination of the lower court that the directors did not owe a duty of care to the plaintiffs as there was no direct connection between acts or omissions of the directors and the harm caused to the plaintiffs. The Court held that the circumstances in which directors could be held personally liable in negligence for the acts of the corporation were limited and not met in this case. The Court found that the defendants had only recently become directors when the representative of the community advised them of the potential violence and it was not claimed that the directors directly operated the Copper Mesa entities or authorized the violence, nor was it specified how the policies and practices of the corporation led to violence. The Court was not sympathetic to the argument that the directors had been informed and that silence from the directors in the face of the violence amounted to tacit approval of the violence against the plaintiffs (Piedra v. Copper Mesa 2011).

In the three HudBay cases, it appears that Ontario courts may be prepared to recognize that HudBay owes a duty of care to the plaintiffs from El Estor. The Ontario Superior Court has rejected a motion filed by HudBay to strike the claims, finding that it is not "plain and obvious" that the actions will not succeed. In doing so, the Court acknowledged that parent companies may owe a duty of care to individuals in foreign countries to prevent harm caused by "security 
personnel at its foreign operations when there is direct control by the Canadian parent corporation" (Choc v. HudBay 2013, para. 73). The Court found that the plaintiffs have alleged facts which, if proven at trial, could establish the elements of foreseeability and proximity necessary to establish a duty of care. The Court stated that acts such as "requesting a forced eviction of a community using hundreds of security personnel" and "authorizing the use of force in response to peaceful opposition from the local community" would make it reasonably foreseeable to Hudbay/Skye that violence would result, including "raping the plaintiffs" and "killing Adolfo Ich and seriously injuring German Chub" (Choc v. Hudbay 2013, paras. 63-64). The Court found that HudBay's public commitment to maintaining a relationship with local communities is a factor in finding that a relationship of proximity may be established at trial.

Because this decision is the result of a preliminary proceeding only, the existence of this duty of care will have to be established at trial. However, it is important to note that HudBay has decided not to appeal this preliminary decision, and the case will proceed to be tried on its merits.

\section{ACCESS TO JUSTICE}

A resolution of conflict between mining corporations and communities does not automatically require a judicial determination in the Canadian courts. In fact, some aspects of the El Estor cases make judicial resolution impractical. For example, threats of violence to potential plaintiffs and witnesses can prevent evidence from being brought forward, regardless of whether a case is heard in Canada or in the jurisdiction in which the alleged incidents occurred. There is also a significant difficulty where the plaintiffs have limited access to funds to retain counsel. Additionally, the present cases against HudBay will not resolve underlying political issues such as the decades-long dispute over land rights. Nevertheless, due to significant shortcomings of other dispute resolution mechanisms, a Canadian judicial determination on the merits may be the only practical way, at the present time, for resolving issues raised in the El Estor cases. The court system in Guatemala would likely not be reliable, as the judicial system in Guatemala appears "open to external interference and is highly politicized" (United Nations 2009a, 2), and the outcome of a judicial process could be influenced by mining interests. The

Lote Nueve case, plagued by concerning administrative delays, evidences the significant barriers faced by mine-affected plaintiffs. In any event, a decision against a Guatemalan subsidiary may 
not effect the necessary change in the parent company's practices, nor be sufficient to impose the rule of law on Canadian executives.

CSR mechanisms are not adequate for resolving serious allegations of human rights abuses against Canadian mining companies. Mechanisms coordinated by the mining company are ineffective when the company disputes the basic facts alleged by the complainants. Mechanisms coordinated by a third party, such as the Corporate Social Responsibility Counsellor or the National Contact Points of the OECD, are voluntary and not enforceable. Given the limitations of alternative mechanisms for resolving these disputes, there is a lack of adequate accountability measures with respect to Canadian mining companies with operations in other jurisdictions. We find it contradictory that profits can travel freely from Guatemala to Canada, while the Canadian beneficiaries would not have to take responsibility for how that money is raised or what activities occur in order to produce the profits. Canadian courts do have the ability to fill the void. As demonstrated by the cases of Anvil Mining, Cambior, and Copper Mesa, legal obstacles such as jurisdiction, forum non conveniens, and duty of care can prevent cases like these from being tried on their merits in Canada. However, Choc v. HudBay may represent an important change in course, at least with respect to duty of care.

As discussed above, the Ontario Superior Court has now acknowledged that parent companies may owe a duty of care to individuals in foreign countries to prevent harm caused by "security personnel at its foreign operations when there is direct control by the Canadian parent corporation" (Choc v. HudBay 2013). If the trial court confirms this finding, individuals alleging injury caused by Canadian mining operations will have access to an enforceable mechanism of accountability. While other barriers such as the doctrines of jurisdiction and forum non conveniens, cost of litigation, and availability of evidence will still exist, we may be at the beginning of a shift in judicial thinking on the relationship between Canadian transnational corporations and the individuals at the location of operations. Until such time as the Guatemalan judiciary is strengthened and is able to act, the Canadian courts may be most viable forum. ${ }^{11}$

In a globalized world, encouraging ethical behaviour cannot be left to a single jurisdiction or a single institution. We hope that the time will come when Canadian courts begin to participate in creating the mechanisms necessary to close the gap in corporate accountability. In the words of retired Supreme Court of Canada judge, Ian Binnie, "Applying our law to 
situations outside of our territory is contrary to our custom; but there are acts that are so repugnant that they must force us to rethink our law" (Boisvert 2012). ${ }^{12}$

\section{References}

Anvil. 2005. “Anvil Annual Report 2005”. http://www.anvilmining.com/files/2005anvilannualreport.pdf.

Association Canadienne Contre L'impunité (ACCI) c Anvil Mining Ltd. 2011. 2011 QCCS 1966. Quebec Court of Appeal.

Ball, Patrick, Paul Kobrak and Herbert Spirer. 1999. State Violence in Guatemala, 1960-1996: A Quantitative Reflection. Washington, D.C.: American Association for the Advancement of Science.

http://shr.aaas.org/projects/human_rights/guatemala/report/Guatemala_en.pdf.

Behrens, Susan Fitzpatrick. 2009. 'Nickel for Your Life: Q'eqchi' Communities Take On Mining Companies in Guatemala." North American Congress on Latin America. https://nacla.org/node/6177.

Boisvert, Yves. 2012. "L'impunité de nos société minières." La Presse, November 5. http://www.lapresse.ca/debats/chroniques/yves-boisvert/201211/04/01-4590272limpunite-de-nos-societes-minieres.php.

Bradbury, J.H. 1985. "International Movements and Crises in Resource Oriented Companies: The Case of Inco in the Nickel Sector." Economic Geography 61(2): 129-43.

Caal v. HudBay. 2011. "Caal v. HudBay Amended Statement of Claim." http://www.chocversushudbay.com/legal-documents.

Canadian Broadcasting Corporation. 2011. "Unfinished Business.” Sunday Edition. http://www.cbc.ca/video/player.html?clipid=2141604355\&position=990702\&site=cbc.ne ws.ca.

Choc v. HudBay. 2013. 2013 ONSC 1414. Ontario Superior Court of Justice.

Choc v. HudBay. 2010. "Choc v HudBay, Second Amended Fresh as Amended Statement of Claim." http://www.chocversushudbay.com/legal-documents.

CNN Money. 2006. "Cambior Inc: Omai Lawsuit Struck and Dismissed." http://money.cnn.com/news/newsfeeds/articles/marketwire/06178759.htm.

Constitutional Court. 2011. Expediente 934-2010. Constitutional Court of Guatemala.

CSR Counsellor. 2011. "Closing Report Request for Review File \#2011-01-MEX." http://www.international.gc.ca/csr_counsellor-conseiller_rse/publications/2011-01MEX_closing_rep-rap_final.aspx.

Chub v. HudBay. 2011. "Chub v. HudBay; Amended Statement of Claim Filed October 26, 2011." http://www.chocversushudbay.com/legal-documents.

Civil Code of Québec, S.Q., 1991, c. 64.

Dashwood, Hevina S. 2012. The Rise of Global Corporate Social Responsibility: Mining and the Spread of Global Norms. Business and Public Policy. Cambridge: Cambridge University Press.

Department of Foreign Affairs. n.d. "Office of the Extractive Sector Corporate Social Responsibility (CSR) Counsellor." Department of Foreign Affairs and International Trade. http://www.international.gc.ca/csr_counsellor-conseiller_rse/index.aspx?view=d. 
Donoghue v. Stevenson. 1932. 1932 UKHL 100. House of Lords.

Driever, Steven. 1985. "The Role of Lateritic Nickel Mining in Latin American Countries with Special Reference to Exmibal in Guatemala." GeoJournal 11: 29-42.

Eslava, Luis. 2008. "Corporate Social Responsibility and Development: A Knot of

Disempowerment.” Sortuz: Oñati Journal of Emergent Socio-legal Studies 2(2): 43-71.

Gerardi, Monisgnor Juan. 1998. "Informe Para La Recuperación de La Memoria Histórica:

Nunca Más”. Oficina de Derechos Humanos del Arzobispado de Guatemala. http://www.odhag.org.gt/03publicns.htm.

Global Reporting Initiative. n.d. https://www.globalreporting.org/Pages/default.aspx.

Grainger, Sarah. 2009. "Land Dispute Threatens Major Guatemala Nickel Project." Reuters, October 12. http://www.reuters.com/article/idUSN1254892220091012.

Grandia, Liza. 2006. 'Unsettling: Land Dispossession and Enduring Inequity for the Q' eqchi' Maya in the Guatemalan and Belizean Frontier Colonization Process." PhD, Berkley: University of California - Berkeley.

Guatemalan Commission for Historical Clarification. 1999. Guatemala: Memory of Silence. http://shr.aaas.org/projects/human_rights/guatemala/ceh/mos_en.pdf.

Guyana Office for Investment. n.d. "Mining." Guyana Office for Investment. http://www.goinvest.gov.gy/mining.html.

HudBay Minerals. n.d. "The Facts: Hudbay's Former Operations in Guatemala." http://www.hudbayminerals.com/English/Responsibility/CSR-Issues/The-facts-Hudbaysformer-operations-in-Guatemala/default.aspx. . 2008a. "Hudbay Minerals Completes Business Combination With Skye Resources; Announces New Director and Chief Financial Officer." http://www.hudbayminerals.com/default.aspx?SectionId=5cc5ecae-6c48-4521-a1ad480e593e4835\&LanguageId=1\&PressReleaseId=c0e9ae5e-c314-4898-8008$137 \mathrm{ec} 8 \mathrm{~d} 9 \mathrm{c} 764$. . 2008b. "Hudbay Reports Third Quarter Results." http://www.hudbayminerals.com/English/Media-Centre/News-Releases/News-ReleaseDetails/2008/HudBay-Reports-Third-Quarter-Results/default.aspx.

- 2009. "HudBay Minerals Provides Update on CGN."

http://www.hudbayminerals.com/English/Media-Centre/News-Releases/News-ReleaseDetails/2009/HudBay-Minerals-Provides-Update-on-CGN/default.aspx. . 2011. "HudBay Minerals Announces Completion of Sale of Fenix Project and Key Management Appointments." http://www.hudbayminerals.com/default.aspx?SectionId=5cc5ecae-6c48-4521-a1ad480e593e4835\&LanguageId=1\&PressReleaseId=c4c56f9d-8be7-4600-898f3b07f7aa8eac.

—. 2012. "2012 Corporate Social Responsibility Report". http://www.hudbayminerals.com/files/doc_downloads/csr/5961_Hudbay_CSR_2012_EN G.pdf.

Imai, Shin, Ladan Mehranvar, and Jennifer Sander. 2007. "Breaching Indigenous Law: Canadian Mining in Guatemala." Indigenous Law Journal 6: 101.

International Labour Organization. 2007. "Report of the Committee Set up to Examine the Representation Alleging Non-observance by Guatemala of the Indigenous and Tribal Peoples Convention, 1989 (No. 169).” 
http://www.ilo.org/dyn/normlex/en/f?p=1000:50012:0::NO:50012:P50012_COMPLAIN

T_PROCEDURE_ID,P50012_LANG_CODE:2507321,en:NO.

Kamphuis, Charis. 2012. "Canadian Mining Companies and Domestic Law Reform: A critical legal account" (2012) 13:9 German Law Journal 1456-1486.

Klippensteins. n.d. "Choc v. HudBay Minerals Inc. \& Caal v. HudBay Minerals Inc." http://www.chocversushudbay.com.

_. 2009. "Piedra v. Copper Mesa Mining Corporation: Statement of Claim," http://www.ramirezversuscoppermesa.com.

Lemco, Jonathan. 1986. "Canadian Foreign Policy Interests in Central America: Some Current Issues." Journal of Interamerican Studies and World Affairs 28:2: 119.

Lewis, Stephen. 1979. "INCO Strike Leaves Bitter Legacy." Toronto Star, April 15, sec. A20.

McFarlane, Peter. 1989. Northern Shadows: Canadians and Central America. Toronto, Ont., Canada: Between the Lines.

Mining Association of Canada. 2011. "Toward Sustainable Mining”. Mining Association of Canada. http://www.mining.ca/www/media_lib/TSM_Documents/protocols_2012/TSM\%20ABO RIGINAL\%20AND\%20COMMUNITY\%20OUTREACH\%20PROTOCOL.pdf."

Mining Watch. 2010. "Class Action Filed Against Anvil Mining by Congolese Victims." http://www.miningwatch.ca/article/class-action-filed-against-anvil-mining-congolesevictims.

Mission in the Democratic Republic of Congo. 2005. "Report on the Conclusions of the Special Investigation into Allegations of Summary Executions and Other Violations of Human Rights Committed by the FARDC in Kilwa (Province of Katanga) on 15 October 2004". United Nations. http://www.abc.net.au/4corners/content/2005/MONUC_report_oct05.pdf.

OECD. 2011. "OECD Guidelines for Multinational Enterprises." Organization for Economic Co-operation and Development. http://www.oecd.org/daf/inv/mne/48004323.pdf.

Paley, Dawn. 2007. “This Is What Development Looks Like.” The Dominion. http://www.dominionpaper.ca/articles/900.

Piedra v. Copper Mesa Mining Corporation. 2011. 2011 ONCA 191.

Prensa Libre. 2012. "Militar Queda En Prisión Por Asesinato de Adolfo Ich Chamán.” Prensa Libre, October 2. http://www.prensalibre.com/noticias/justicia/Militar-asesinato-AdolfoIch-Chaman_0_784124821.html.

Recherches Internationales Québec v. Cambior Inc. 1998. Q.J.No. 2554. Quebec Superior Court.

Rittich, Kerry. 2006. "The Future of Law and Development: Second-Generation Reforms and the Incorporation of the Social." In The New Law and Economic Development : A Critical Appraisal.

Rodriguez, James. 2009. “Barrio La Union Leader Killed by CGN's Security Agents in El Estor." MiMundo. http://www.mimundo.org/2009/09/29/barrio-la-union-leader-killed-bycgn $\%$ E2\% 80\%99s-security-agents-in-el-estor/.

Sagebien, J., and N. Lindsay. 2011. Governance Ecosystems: CSR in the Latin American Mining Sector. SCFAIT. 2005. "Fourteenth Report: Mining in Developing Countries-Corporate 
Social Responsibility". Standing Committee on Foreign Affairs and International Trade. http://cmte.parl.gc.ca/cmte/CommitteePublication.aspx?COM=8979\&Lang=1\&SourceId $=178650$.

Skye Resources. 2007. "Land Occupations End at Fenix Project.” Schnoor v. Canada. http://www.schnoorversuscanada.ca/docs/skye-pr.pdf.

Trubek, David M. 2006. The New Law and Economic Development: a Critical Appraisal. Cambridge ; New York: Cambridge University Press.

United Nations. 2002. "Report of the United Nations Verification Mission in Guatemala ('MINUGUA') for the Consultative Group Meeting for Guatemala." http://www.iadb.org/regions/re2/consultative_group/gu/minugua_eng.pdf. . 2009a. "Report of the Special Rapporteur on the Independence of Judges and Lawyers, Leandro Despouy". A/HRC/11/41/Add.3. http://daccess-ddsny.un.org/doc/UNDOC/GEN/G09/162/20/PDF/G0916220.pdf. . 2009b. "Promotion and Protection of All Human Rights, Civil, Political, Economic, Social and Cultural Rights, Including the Right to Development: Report of the Special Rapporteur on Extrajudicial, Summary or Arbitrary Executions, Philip Alston, Addendum: Follow-up to Country Recommendations - Guatemala”. A/HRC/11/2/Add.7. http://www.geneva-academy.ch/RULAC/pdf_state/G0913064.pdf. . 2011. "Guiding Principles on Business and Human Rights". A /HRC/17/31. http://www.business-humanrights.org/media/documents/ruggie/ruggie-guidingprinciples-21-mar-2011.pdf.

UN News Center. 2013a. "Justice in Guatemala Vital for Preventing Recurrence of Heinous Crimes, Say UN Experts.” UN News Center. http://www.un.org/apps/news/story.asp?NewsID=44918\&Cr=guatemala\&Cr1=\#.UZutD LWmiAg.

—. 2013b. "UN Human Rights Office Urges Trial to Be Decided on Merits after Guatemalan Court Overturns Ríos Montt Conviction." http://www.un.org/apps/news/story.asp?NewsID=44993\#.UaQ185zNkv0.US Department of State. 2012. "Guatemala 2012 Human Rights Report". US Department of State. http://www.state.gov/j/drl/rls/hrrpt/humanrightsreport/index.htm?year=2012\&dlid=20445 4.

Voluntary Principles on Security and Human Rights. n.d. http://www.voluntaryprinciples.org.

1. This section is based in part on Imai, Mehranvar, and Sander (2007) section II.

2. At the time it was called International Nickel Company. It officially changed its name to INCO in 1976. See McFarlane 1989.

3 Carlos Arana Osorio was elected as president in 1970, in what was referred to as a "fraudulent election". Upon his election, Arana stated that he would, if necessary, "turn the country into a cemetery in order to pacify it". See McFarlane 1989, 130.

4. For example, Oliverio Castañeda de León, a member of the University Student Association, was machine gunned to death in broad daylight in front of hundreds of witnesses including police. The police did not attempt to chase or arrest the shooters; Gerardi 1998.

5. Note that the first evictions in November took place without a court order, which is required by Guatemalan law: Paley 2007.

6 The recent conviction at first instance of Ríos Montt, Guatemala's former military leader, in Guatemalan Courts for genocide and crimes against humanity during the civil war represents an important step in Guatemalan's fight against impunity. (UN News Center 2013a). However, the verdict was annulled by the Constitutional Court a few days later (UN News Center 2013b).

7. For photos of Lote 9 see University of Northern British Columbia.

8. Fontierras or "Fondo de Tierras" is a state entity responsible for keeping a registry of land titles.

9. For a description of litigation in Canada and the Interamerican system, see North and Young (2013). 
10. Much of the conflict in and around Junin between farmers, the security forces and the mining community has been filmed by Malcolm Rogge in his documentary film, Under Rich Earth. See the website at 〈http://underrichearth.ryecinema.com/?page_id=114>.

11 There is significant support for legislation in Canada that would provide accountability for the activities of extractive industries in other countries, but attempts at a legislative solution have not been successful. For a full discussion, see, Kamphuis (2012).

12. <<Appliquer notre droit à des situations à l'extérieur de notre territoire est contraire à nos conceptions; mais il y a des actes tellement répugnants qu'ils doivent nous forcer à revoir nos conceptions du droit. Au XVIIIe siècle, la piraterie posait une telle menace qu'on pouvait juger les pirates sans égard au lieu de leurs crimes.». 